\title{
CONVITE A LEITURAS SOBRE ESCOLA E EDUCAÇÃO
}

Prezad@s Leitor@s,

São 12 os artigos que compõem esta $18^{a}$ edição de e-Mosaicos, sendo que quatro constituem a seção especial "Violência, indisciplina e bullying na escola", proposta pelo Professor Dr. José Antônio Vianna, do Instituto de Educação Física e Desporto da UERJ e, também, membro do corpo docente do PPGEB/CAp-UERJ.

O primeiro artigo, de autoria de Ana Paula Santos e Leandro Britto, tece um diálogo entre a questão da educação em direitos humanos e as questões de gênero no cotidiano da escola. "Carolina: Marias que não se calam", de autoria de Ana Muniz, Alexsandro Soares e Cristiana Callai, possibilita ao leitor revisitar, pelas narrativas de estudantes, o livro Quarto de despejo: diário de uma favelada, este, de Carolina de Jesus. Em "Narrativas de formação: potencialidades e possibilidades para a pesquisa em educação", os autores Elder Pereira e Benedito Eugenio apresentam contribuições da narrativa para a pesquisa autobiográfica. Angela Cagliari e Andréia Zucolotto propõem, por meio de um artigo de revisão bibliográfica, uma análise de artigos científicos que discorrem sobre as relações entre museu e escola. $O$ teatro como possibilidade de divulgação científica é o tema do artigo de Ademir Pereira e de Vivian Calixto, tendo como foco um projeto de extensão universitária na área de ensino da Química. Ainda no campo do despertamento do interesse pela ciência, o artigo de Igor Carvalho, Marcelo Rocha e Pedro Costa parte da investigação de duas revistas científicas, uma brasileira e outra portuguesa, respectivamente, a Superinteressante e a Quero Saber, para abordar o conhecimento científico sobre a temática aquecimento global e o que propagam essas revistas de divulgação científica. A história da Física é tema do artigo de autoria de Nádia Pereira e de Mauro Sérgio Araújo, que a consideram um recurso capaz de tornar o ensino de Física mais crítico e mais contextualizado com a realidade vivenciada pelos estudantes da educação básica. Para encerrar a seção "Artigos", Humberto Fortunato e Yolanda Vançato apresentam um projeto de divulgação e de extensão científica que tem como temática o ensino de Biologia marinha para adolescentes.

A seção especial apresenta quatro artigos que dialogam com a temática violência, indisciplina e bullying no cotidiano da escola. O primeiro artigo da seção, "Escola e violência: a busca por uma ampliação do termo violência escolar frente à realidade brasileira", de autoria de Leonardo Marino, propõe algumas indagações sobre o tema violência escolar, visando a compreensão desse conceito e possibilitando entender como a violência vem se ampliando no cotidiano escolar. Monique Longo discute os conceitos violência escolar, homicídios, conflitos interpessoais, bullying, agressões físicas e verbais no cotidiano da escola e nas mídias, ressaltando a importância de se inserir essas temáticas nos espaços de 
DOI: $10.12957 /$ e-mosaicos.2019.45481

formação docente, tendo com locais de pesquisa Instituições de Educação Superior. Ana Martins e Cláudia Sonco apresentam resultados de uma pesquisa de mestrado que busca analisar as percepções de escola e família sobre bullying e o papel da orientação educacional. $O$ último artigo da seção e desta edição da revista apresenta "Os sentidos de bullying nas vozes das crianças do Ensino Fundamental: aprendendo e crescendo com os conflitos na escola" a partir de atividades desenvolvidas por meio de um projeto de Iniciação à Docência no CAp-UERJ.

Mais uma vez, desejamos uma excelente leitura e que a e-Mosaicos possa contribuir para processos formativos e de pesquisa de seus leitores.

Andrea da Paíxão Fernandes Editora Geral de e-Mosaicos 